\title{
LEGION ŻYDOWSKI - MISTYCZNY TESTAMENT AdAMA MickiewicZa
}

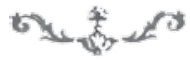

Przed śmiercią Adam Mickiewicz żałował, że tego [legionu żydowskiego - A.F.] nie doprowadził do skutku, powtarzając nieraz: jak mnie nie stanie, to tego nikt i nie zrozumie.

Michał Czajkowski (Sadyk Pasza) ${ }^{1}$

rozumienie fenomenu, jakim była inicjatywa Adama Mickiewicza,
sprowadzająca się do utworzenia legionu żydowskiego w Turcji podczas
wojny krymskiej, wymaga spojrzenia na nią z perspektywy całej twórczości

1 Wspomnienie Michała Czajkowskiego (Sadyka Paszy); cyt. za: R. Brandstaetter, Legion żydowski Adama Mickiewicza (dzieje i dokumenty), Warszawa 1932 (odbitka z „Miesięcznika Żydowskiego"), s. 35. Książka Brandstaettera jest jak dotąd najpełniejszym zbiorem dokumentów i relacji, dotyczących tzw. legionu żydowskiego. Ustalenia materiałowe Brandstaettera stały się podstawą opracowania historii legionu w ostatnim tomie Kroniki życia i twórczości Mickiewicza (por. K. Kostenicz, Ostatnie lata Mickiewicza. Styczeń 1850 - 26 listopada 1855, Warszawa 1978, s. 447-518). Opracowanie Kseni Kostenicz uwzględnia jednak w szerszym kontekście kontakty Mickiewicza ze światem żydowskim w ostatnich miesiącach życia. Po blisko siedemdziesięciu latach od publikacji „Miesięcznika Żydowskiego” problematyką legionu zajęła się Maria Janion, drukując na łamach czasopisma „Midrasz” (1998, nr 4) artykuł Legion żydowski Mickiewicza, przedrukowany następnie w książce Do Europy tak, ale razem z naszymi umartymi (Warszawa 2000, s. 73-100) oraz w Bohater, spisek, śmierć. Wykłady żydowskie (Warszawa 2009, s. 223-258). Dodać należy także artykuł: A. Witkowska, Żydowski legion, w: J.M. Rymkiewicz, D. Siwicka, A. Witkowska, M. Zielińska, Mickiewicz. Encyklopedia, Warszawa 2001. 
poety. A twórczość ta nie może być ograniczana tylko do dzieł literackich. Granice literackości dawno już poszerzono, obejmując nimi także epistolografię poety, jego publicystykę, wykłady, ale także to wszystko, co nie zostało bezpośrednio zwerbalizowane, pozostało w pamięci jako wypowiedź, sugestia, działanie. W przypadku bowiem Mickiewicza (ale także innych twórców romantycznych) nie tylko poezja sensu stricto jest poezją. W obrębie kreacji sensu largo muszą znajdować się inne rodzaje ekspresji, także te, które nie mają nic wspólnego z literaturą w jej dosłownym, wąskim rozumieniu.

Takim właśnie nieliterackim wyrazem kreacji twórczej był tak zwany legion żydowski, formacja wojskowa złożona z Żydów, którzy, powodowani motywacją religijną, polityczną lub jakąkolwiek inną, chcieliby walczyć przeciwko Rosji. I właśnie idea stworzenia takiego legionu najpełniej ilustruje ówczesny sposób myślenia Mickiewicza o świecie. Zamilkł od dawna jako artysta, ale zachował aktywność społeczną, angażując się jednocześnie na polu działalności historycznej, politycznej i religijnej. Właśnie te trzy płaszczyzny, wzajemnie sprzężone i wzajemnie się objaśniające muszą zostać zbadane, by zrozumieć sens inicjatywy tworzenia formacji żydowskiej, by pojąć to, o czym Mickiewicz (we wspomnieniu Sadyka Paszy) mówił jako o czymś niepojętym.

Na początek trzeba przyjrzeć się zatem historycznemu kontekstowi inicjatywy legionu żydowskiego. Do Mickiewicza 31 maja 1855 roku zgłosił się ajent polityczny księcia Adama Jerzego Czartoryskiego z Belgradu, Ludwik Lenoir-Zwierkowski. Zapoznał poetę $\mathrm{z}$ antagonizmem, jaki podzielił księcia Adama i generała Władysława Zamoyskiego. Zamoyski - zdaniem księcia - dwulicowo postępował wobec Sadyka Paszy, którego z kolei Czartoryski obdarzał w sprawach tureckich pełnym zaufaniem ${ }^{2}$. Źródłem konfliktu było postępowanie Zamoyskiego, który podszedł Sadyka Paszę. Gdy ten bowiem wyjednał u sułtana licencję na tworzenie II pułku kozaków otomańskich, Zamoyski zaczął pertraktacje ze sztabem angielskim, by przejść na żołd brytyjski. Brytyjskie zaplecze finansowe dawało pewność otrzymywania żołdu, co z kolei było równoznaczne z kaperowaniem oficerów z I pułku Sadyka Paszy do własnej, konkurencyjnej wobec niego formacji. Mickiewicz nie pierwszy raz zetknął się z krecią robotą Zamoyskiego. W 1848 roku musiał neutralizować - podobne do stambulskich - jego próby przejęcia Legionu rzymskiego i wpisania tej inicjatywy w stare schematy, będące - zdaniem poety towiańczyka - negacją duchowego wysiłku³.

2 R. Brandstaetter, dz. cyt., s. 1.

3 Por. Adama Mickiewicza wspomnienia i myśli, z rozmów i przemówień zeb. i oprac. S. Pigoń, Warszawa 1958, s. 244-245. 
Jeszcze w czerwcu 1855 roku Mickiewicz miał powiedzieć Lenoir-Zwierkowskiemu, że gdyby tylko miał fundusze, pojechałby do Turcji z misją pogodzenia Zamoyskiego i Sadyka Paszy, a także w celu dopomożenia rekrutacji Polaków do wojska.

Skoro by [inni] ujrzeli, że ja ze zbielałą głową, ale z gorącym sercem idę tam, gdzie ono mi wskazuje, równie jak rozum, już nie wyższy, ale po prostu chłopski rozum, że Polskę znaleźć można, a zatem szukać jej należy: toby młodzi i zdolniejsi, bo są żołnierze, nie śmieli może dłużej gnić, żebrać, jeśli nie co gorzej, a nie spełnić świętego obowiązku. ${ }^{4}$

Fundusze się znalazły i Mickiewicz wyjechał z ramienia francuskiego ministerstwa oświaty w celu przeprowadzenia badań nad kulturą Słowian południowych. W drodze towarzyszyli mu: syn księcia Adama, Władysław, Henryk Służalski, emigrant, urzędnik kolei żelaznej w Paryżu i sekretarz, Armand Lévy. Mickiewicz wyjechał z Paryża 11 września, a 22 września był już w Konstantynopolu. Nie zastawszy Sadyka Paszy w stolicy, podążył do obozu wojennego w Burgas. Przybył tam z jak najlepszym nastawieniem. Jak pisze Maria Czapska, „imieniem i tradycją formacja kozaków ottomańskich była poecie bliższą od czysto polskiej dywizji, którą miał formować Zamoyski pod dowództwem angielskim, bliższa sprawie polskiej, bardziej płodna na przyszłość"s. Dodać tu trzeba, że Mickiewicz niejednokrotnie opowiadał się za budowaniem całości złożonej z różnorodnych części. Był, można powiedzieć, zwolennikiem jedności złożonej z rozmaitych elementów kulturowych, religijnych, etnicznych. W relacji Lenoir-Zwierkowskiego z przywoływanej już rozmowy z Mickiewiczem czytamy:

Ludzie się znajdą, sami przyjdą do rzeczy dobrze poprowadzonej, tylko - zamiast rzeczy rozłączać kwalifikacjami i celami osobistymi, że to polskie i katolickie, a to tureckie i kozackie - trzeba wiązać, łączyć, jednoczyć, przymnażać, gdyż inaczej sami ziarna rozdwojeń posiejemy tam, gdzie już węzły osłabły i ostygły, jak na Rusi i Ukrainie. Sadykowi wyrzucają, że brał Żydów i Bułgarów, i Cyganów, ale mu ci to zarzucają, co sami nic nie chcą robić i gniewają się, że on coś robi. ${ }^{6}$

Konfrontacja wyobrażeń z rzeczywistością wypadła bardzo korzystnie. Mickiewicz i Lévy byli wręcz zachwyceni życiem obozowym. Wędrując wśród żołnierzy, Mickiewicz natknął się na grupę żołnierzy - Żydów, walczących pod chorągwią kozacką przeciwko Rosji. Wtedy zapewne narodził się pomysł zorganizowania odrębnej formacji złożonej z Żydów I i II pułku. Lévy w liście do Emila Bednarczyka pisał, że myśl ta sformułowała się jedno-

Tamże, s. 256.

5 M. Czapska, Szkice mickiewiczowskie, Warszawa 1999, s. 303.

6 Adama Mickiewicza wspomnienia i myśli, s. 261-261. 
cześnie w jego głowie, głowie Mickiewicza i Sadyka Paszy, co było dla nich dowodem opatrznościowej, a nie ludzkiej inspiracji tej idei . Dostrzegamy tu stylizację na pojawiający się w piśmiennictwie mistycznym topos, w którym wspólnotowe myślenie ma stawać się dowodem łączności ludzi z Bogiem. Na przykład legenda o przekładzie Tory na język grecki, o stworzeniu Septuaginty, miała być właśnie potwierdzeniem natchnionego charakteru tekstu, który nie był już przecież oryginałem hebrajskim. Jednak pamiętać trzeba, że wątki żydowskie w myśli i dziełach Mickiewicza przewijały się już od czasów filomackich ${ }^{8}$. Na pewno więc pomysł, który mógł spontanicznie pojawić się w głowach Lévy’ego czy Sadyka Paszy, w głowie Mickiewicza (nie negując spontaniczności, natchnieniowego charakteru samej idei) miał bardzo głębokie zaplecze: historyczne, społeczne, polityczne, wreszcie mistyczne.

W pierwszym pułku Kozaków otomańskich służyło około dwustu Żydów. Byli to jeńcy z armii rosyjskiej, którzy dobrowolnie chcieli teraz walczyć przeciwko Rosji. Oni właśnie mieli stać się trzonem formacji żydowskiej. Dzięki staraniom Mickiewicza w obozie w Burgas stanęła synagoga ${ }^{9}$, wszczęto energiczne starania zmierzające do pozyskania zaplecza finansowego dla formacji żydowskiej. W swoich wspomnieniach Sadyk Pasza relacjonuje:

R. Brandstaetter, dz. cyt., s. 4 .

8 Skrupulatnie pisze o tym poznański badacz, Krzysztof A. Makowski, w artykule Wqtek żydowski w badaniach nad Mickiewiczem (w: Księga Mickiewiczowska. Patronowi uczelni $w$ dwusetna rocznice urodzin 1798-1998, pod red. Z. Trojanowiczowej i Z. Przychodniaka, Poznań 1998). Makowski podkreśla, że „Mickiewicz już w młodości przejawiał szczególne zainteresowanie sprawami Żydów. [...] W Wilnie utrzymywał osobiste kontakty z Izraelitami, m.in. ze studentami Lewim i Neimanem oraz drukarzem Manesem. Mickiewicz miał się też uczyć wtedy hebrajskiego u znanego filologa klasycznego i hebraisty wileńskiego, ks. Szymona Żukowskiego” (s. 439). Następnie stwierdza, że zdaniem Mickiewicza „Żydzi mieli swą duchowością i żarliwością rozpalić Polaków albo działać jako katalizator we wprowadzaniu nowej epoki” (s. 445). Mickiewicz w każdym aspekcie wyrastał tu ponad standard zainteresowania problematyką żydowską w tej epoce. „Wszelkie twierdzenia - konstatuje trafnie Makowski - że postawa Mickiewicza wobec Żydów była typowa dla owych czasów, są, moim zdaniem, nie do obronienia” (s. 449). Dodajmy do tego konstatację Artura Eisenbacha, który podkreślał, że już w prelekcjach paryskich „Mickiewicz rozwijał paralele między narodem polskim i żydowskim, dostrzegał analogie w przyczynach upadku ich państw. Mickiewicz wierzył, że koncentracja Żydów w Polsce jest skutkiem wyroków boskich. Wielokrotnie wraca do tej myśli, zwłaszcza w wykładzie z 23 kwietnia 1844”; ponadto kilkudziesięciu Żydów należało do włoskiego legionu Mickiewicza, zaś Skład zasad, zarysowując przyszły ustrój Polski, gwarantował Żydom pełne równouprawnienie. Zob. A. Eisenbach, Emancypacja Żydów na ziemiach polskich 1785-1870 na tle europejskim, Warszawa 1988, s. 363-364.

R. Brandstaetter, dz. cyt., s. 11 
Przywiózł [Lévy] mi do Szumny bogi żydowskie, Talmud, żydowskie księgi, koszule, jak je zowią, śmiertelne, suknie i ogromną ilość pak ze sprzętami religijnymi. Wszystko było warte najmniej pięćdziesiąt tysięcy franków, dar bogaty, zwyczajnie dar jednego z rodziny królewskiej finansów. Przy tym był model munduru, spodnie czekoladowego koloru, mantyl żółty, dolman czekoladowy, a wszystko szamerowane złotem. Był to gest młodego Rotszylda. Adam Mickiewicz żartując mówił p. Zamoyskiemu, że to były barwy kapucynów i bernardynów. ${ }^{10}$

Możemy to interpretować jako znaki powrotu pewnej religijnej pierwotności, gdy chrześcijaństwo znajdowało się jeszcze bardzo blisko judaizmu, gdy nie wykopano przepaści między wyznawcami obu religii. Mickiewicz, w przeciwieństwie do swoich współczesnych, a nawet Towiańskiego, nie podzielał przekonania o konieczności wyrzeczenia się przez Żydów „historycznego błędu” i uznania boskiej Istoty w Chrystusie. Było to wyrazem jego głębokich przekonań o duchowej proweniencji jedności zbudowanej z różnorodnych elementów. Jednocześnie szczęśliwie rymowało się z oczekiwaniami ewentualnych darczyńców, których szczodrość mogła zapewnić materializację owej idei. Dlatego najzupełniej szczerze Lévy mógł pisać do Alfonsa Rothschilda, iż legion będzie oparty na tradycji żydowskiej, z poszanowaniem rytuału, a jego celem będzie także „rehabilitacja narodowa”, ukazania współczesnych Żydów jako następców walecznej tradycji machabejskiej ${ }^{11}$.

Projektem legionu udało się zainteresować barona Camondo, bogatego bankiera żydowskiego w Konstantynopolu, Izraela Landaua, osobistego wysłannika Rothschilda, negocjującego warunki udzielenia Turcji pożyczki wojennej, Benedykta Brunswicka, Żyda francuskiego, który z polecenia Rotschilda organizował szkoły żydowskie w Turcji, wreszcie naczelnego rabina Żydów tureckich, który miał spowodować propagowanie idei legionowej w synagogach ${ }^{12}$.

Mickiewicz upajał się działaniem i - jak pisze Czajkowski - chciał, „żeby się nie kończyło tylko na samych deklamacjach dziennikarzy o braciach wyznania mojżeszowego [...], ale na czynie i to niezaprzeczonym, widocznym i dotykalnym”"13. Ostatecznie projekt skonkretyzował się tak, że spośród Żydów tureckich miało zostać zarekrutowanych około tysiąca żołnierzy, spośród jeńców - kilka tysięcy. Projekt zyskał przychylną opinię dostojników tureckich. Lévy wspomina - w relacji zapisanej przez Władysława Mickiewicza, iż

[...] oficerowie - Żydzi francuscy - przyrzekli, że jak tylko uzyskamy firman upoważniający, zażądają od rządu francuskiego pozwolenia służenia w pułku żydowskim.

M. Czajkowski (Mehmed Sadyk Pasza), Moje wspomnienia o wojnie 1854 roku, oprac.

J. Fijałek, Warszawa 1962, s. 250-251.

11 Por. R. Brandstaetter, dz. cyt., s. 15.

12 Tamże, s. 15, 24-25, 29-30.

13 Biblioteka Polska w Paryżu, rkps nr 876, s. 11. 
Widzieliśmy już nadchodzący dzień, kiedy rozwinięty będzie sztandar Machabeuszów. Mickiewicz uradowany mówił mi: jeżeli wkraczając do Polski, zdołamy żydowskim naszym pułkiem pociągnąć za sobą Żydów jednej bóżnicy, chłopi wątpić nie będą w powodzenie, bo znając przezorność Izraelitów powiedzą sobie: pewnym musi być powodzenie, skoro Żydzi łączą się z powstaniem. I jak lawina toczyć się będziemy z wzrastającą wciąż naszą legią od bóżnicy do bóżnicy, od wioski do wioski, w głąb samej Polski i Litwy. ${ }^{14}$

Wątek propagandowego oddziaływania legionu żydowskiego na Polaków powrócił w relacji Teodora Tomasza Jeża. Otóż Hipolit Kuczyński jeszcze w 1856 roku miał powiedzieć Jeżowi, „że Mickiewicz ostatnią wolą swoją zamianował go polskim wodzem naczelnym i polecił mu organizować niezwłocznie legion żydowski”. Idea Mickiewicza domagała się sukcesji, ponieważ, jak argumentował poeta

[...] pielgrzymstwo żydowskie a pielgrzymstwo nasze to jedno. W organizacji legionu żydowskiego tkwi myśl głęboka a prosta i do zrozumienia łatwa, jak każda myśl wielka. Zważ jeno: gdy w szeregach stanie Żydów dziesięć tysięcy, to przez emulację samą Polaków zgromadzi się sto tysięcy i rezultat pewny. ${ }^{15}$

Znamienne jest, że wojskowi, więc Sadyk Pasza, Bednarczyk, Kuczyński w pomyśle Mickiewicza dostrzegali przede wszystkim jego aspekt praktyczny: organizacja funduszy, zapewnienie bazy poboru do wojska w jeńcach armii rosyjskiej i rzeszach Żydów tureckich, wreszcie pozytywne oddziaływanie na prowojenną postawę Polaków: przez wzbudzenie zaufania w masach chłopskich ${ }^{16}$ oraz emulacji wśród szlachty, która przecież nie mogła dać się ubiec Żydom w okazywaniu uczuć patriotycznych. W wielu relacjach czytamy też o przekonaniu poety, iż sprawa przyszłej niepodległości Polski związana jest z szeroko pojętą kwestią żydowską. „Nie chciałbym - miał powiedzieć do Lévy’ego - by Żydzi wynieśli się z Polski, bo unia Polski z Izraelem jest przeznaczona do wzmocnienia Rzeczypospolitej, jak ongi wzmocniła ją wojskowa z Litwą" ${ }^{17}$. Mickiewicz, zdaniem Lévy'ego, lubił też powtarzać, „[...] że Po-

14 R. Brandstaetter, dz. cyt., s. 21.

15 T.T. Jeż (Zygmunt Miłkowski), Od kolebki przez życie. Wspomnienia, do druku przygotował A. Lewak, wstępem poprzedził A. Brückner, t. 2, Kraków 1936, s. 218.

16 Jak dobrze Mickiewicz znał tu realia wiejskie! Właśnie żydowski arendarz, a nie pleban, ani w żadnym razie dziedzic, był autorytetem obdarzonym przez chłopów największym zaufaniem; brak konfliktu ekonomicznego, ostrożność w interesach, znajomość świata i szerokie kontakty - wszystkie te cechy, zarysowane już w postaci Jankiela z Pana Tadeusza, pewnego rodzaju kulminację uzyskują w idei legionu żydowskiego.

17 R. Brandstaetter, dz. cyt., s. 5. W nieco innej formie opinię tę przywołuje Stanisław Pigoń: „Nie chciałbym, aby Izraelici wyszli z Polski, bo tak jak unia Litwy z Polską, acz różne były ich rasy i religie, dała wielkość polityczną i militarną naszej Rzeczy- 
lacy byli, jak Żydzi, ujarzmieni przez obcych i rozproszeni pomiędzy narodami, by nauczyć się w ten sposób pokory; przewidywał dzień, kiedy chrześcijanie i Izraelici wzniosą się wspólnie do wyższego religijnego poziomu”"18. Odwoływał się więc Mickiewicz do paraleli polsko-żydowskiej, zestawienia, które jeszcze na początku XIX wieku wydawało się szokujące, a wraz z upływem lat niewoli stawało się coraz bardziej realne ${ }^{19}$.

Projekt Mickiewicza mógł wydawać się więc realny, możliwy do realizacji, militarnie i politycznie perspektywiczny. Pozytywne zakończenie pertraktacji w sprawie pożyczki Rothschilda dla Turcji zostało zrozumiane przez inicjatorów legionu jako sygnał do działania. Ustalono, iż formacja żydowska powstanie pod egidą Mickiewicza, jej szefem honorowym zostanie Rothschild, a naczelnym instruktorem - pułkownik Bednarczyk. Pułk finansowany miał być przez Rothschilda, Camondo, Landaua i żydowską ludność Turcji, od której Bednarczyk zaczął już ściągać specjalne podatki. Miał też zostać powołany Naczelny Żydowski Komitet Wykonawczy do pośredniczenia między rządem a społecznością żydowską ${ }^{20}$. Realistyczny, a nie utopijny charakter projektu Mickiewicza podkreśla też fragment Wspomnień Sadyka Paszy, w których czytamy, że „Adam Mickiewicz znał dobrze Polaków, bo zaledwie pojawiła się wieść o tej organizacji, byłem zasypywany prośbami Polaków, szlachty karmazynowej z czasów Piastów i Jagiellonów o przyjęcie ich do tego pułku" ${ }^{21}$. Natomiast pułkownik Mikołaj Korwin Kamieński, waleczny oficer $\mathrm{z} 1831$ roku, prosił o protekcję w wyrobieniu mu dowództwa legionu. Uważał, że jest szczególnie predysponowany do tej funkcji, gdyż, jak

pospolitej, tak wierzę, że unia Polski z Izraelem powiększyłaby naszą siłę duchową i materialną. Najskuteczniejszym przygotowaniem Polski do odrodzenia jest zniszczenie przyczyn jej upadku, to znaczy połączenie i zbratanie wszystkich różnych ras i religii naszej ojczyzny". Adama Mickiewicza wspomnienia i myśli, s. 263.

18 Cyt. za: J.W. Borejsza, Sekretarz Adama Mickiewicza (Armand Lévy i jego czasy 1827-1891), Wrocław 1977, s. 127.

19 Por. A. Fabianowski, Judaizm - Diaspora - Mesjanizm. Romantyczne myślenie analogiami, w: Kwestia żydowska w XIX wieku. Spory o tożsamość Polaków, pod red. G. Borkowskiej i M. Rudkowskiej, Warszawa 2004, s. 43-60. Dodać tu trzeba perspektywę historiozoficzną, która w myśli Mickiewicza oscylowała zawsze w rozmaitych wariantach oraz inwariantach koncepcji mesjanistycznych. Wyczerpująco pisze o tym Wiktor Weintraub w książce Poeta i prorok. Rzecz o profetyzmie Mickiewicza (Warszawa 1982) oraz w pośmiertnie wydanej pracy Mickiewicz - mistyczny polityk (Warszawa 1998). Mesjanizmowi Mickiewicza poświęcił też swe studia Andrzej Walicki (Filozofia a mesjanizm. Studia z dziejów filozofii i myśli społeczno-religijnej romantyzmu polskiego, Warszawa 1970).

M. Czajkowski (Mehmed Sadyk Pasza), dz. cyt., s. 250. 
wspomina Sadyk Pasza, „dla dowodzenia takim pułkiem trzeba umieć się bić na polu bitwy jak szlachcic polski, a trzeba się umieć znachodzić w salonach Rotszylda jak polski magnat"22.

Skoro pomysł utworzenia formacji żydowskiej był tak fortunny, perspektywiczny i skupił na sobie zainteresowanie tak wielu wpływowych osób, to dlaczego Mickiewicz niedługo przed śmiercią mówił: ,jak mnie nie stanie, to tego nikt i nie zrozumie"? Co mogło być niezrozumiałego w idei tak dobrze wpisanej w swój czas historyczny? Odpowiedź na te pytania ma charakter wielostopniowo złożony, zacznijmy więc od kwestii dowództwa legionu. Mickiewicz, podobnie jak to było z legionem rzymskim, na stanowisku dowódcy widział towiańczyka, pułkownika Karola Różyckiego. Różycki wyniósł doświadczenie wojenne z pól bitewnych powstania listopadowego, dowodząc "pułkiem jazdy wołyńskiej”, prywatnie zaś był szwagrem Sadyka Paszy, więc najbardziej znaczącego wtedy polityka polskiego w Turcji. Różycki jako dowódca legionu pozostawał w jakimś stopniu uzależniony od Mickiewicza - brata Adama i w jakimś stopniu zapewniał też poecie wpływ na działania Sadyka Paszy. W jakimś stopniu jeszcze w fazie wstępnej realizacji idei Mickiewicz komenderował Sadykiem Paszą. Gdy generał dziwił się, że polscy oficerowie mają rządzić „p potomkami Machabeuszów”, Mickiewicz miał odparować ostro: „Jeśli Polacy w kraju nie znają albo nie chcą pojąć swojego własnego narodowego interesu, jeśli nie chcą pełnić swojej powinności, trzeba ich zastąpić Izraelitami, a Izraelici jedni będą w stanie nauczyć ich powinności i przyprowadzić do nas" ${ }^{23}$. Mickiewicz chciał więc nie tylko utworzenia legionu, ale także dalszego trwania przy nim, wpływania na bieg wydarzeń, swoistego „duchowego" czy ideowego przywództwa.

Mickiewicz mógł obawiać się, że rozpowszechnione wśród Polaków antyżydowskie uprzedzenia (w tym przekonanie, iż Żydzi nie nadają się na żołnierzy) stanie się przeszkodą nie do przebycia w szczęśliwym sfinalizowaniu jego zamierzenia. Wydaje się, że trafnie odczytał to Józef Bohdan Zaleski, jeszcze w 1842 roku pisząc do szkolnego przyjaciela, Seweryna Goszczyńskiego:

Mesjanizm Mickiewicza jest inszy, po prostu jest to apoteoza judaizmu, nauka arcytwarda mianowicie dla Słowian tak serdecznie chrześcijańskich. [...] Pocznie się zapewnie nowa era, ale w st r ęt y ple mi e n n e niełatwo dają się wykorzeniać przez długie wieki. Wyższość nad sobą d u c h o w ą Żydów nieprędko jeszcze uznają Polacy i w ogólności wszyscy Słowianie. ${ }^{24}$

22 Tamże.

23 Tamże.

24 Korespondencja Józefa Bohdana Zaleskiego, wyd. D. Zaleski, t. 2, Lwów 1901, s. 245; podkr. - A.F. 
„Nauka arcytwarda” obejmowała przecież nie tylko socjopolityczne realia rozległego teatru wojny krymskiej, ale także prawdziwe otchłanie myśli mistycznej, która, szczególnie w okresie towianistycznym, wiele czerpała z mistyki żydowskiej. Andrzej Towiański, wprawdzie kilka lat później, komentując patriotyczno-religijne manifestacje warszawskie w 1861 roku, pisał:

Jak przed wieki w Izraelu, tak dziś w Polsce objawia się widomie moc Boża i tą mocą zachwiana została siła ziemska. Podobne powołanie tych dwóch narodów - Izraela w starym zakonie, aby stał się narodem - urzędem na drodze Bożej, a Polski dzisiaj, aby stała się narodem - urzędem na drodze chrześcijańskiej, która jest tąż samą drogą Bożą, tylko wyższą jej częścią - sprowadziło dla nich podobneż koleje. ${ }^{25}$

Towiański wierny jest koncepcji rozdzielenia drogi judaistycznej i chrześcijańskiej, dostrzega jednak i podkreśla ścisły paralelizm owych dróg. Mickiewicz - jak już wspomniano - nie forsował asymilacji jako koniecznego warunku współpracy chrześcijan z wyznawcami judaizmu. Przeciwnie, podkreślanie rytuałów, pomoc w zachowaniu narodowej i etnicznej odrębności charakteryzowało stosunek poety do Żydów.

Nie wynikało to z jakiegoś ahistorycznego antycypowania przez Mickiewicza dzisiejszych kategorii należących do modelu multikulturowego. Sugerując takie nastawienie poety, popełnilibyśmy anachronizm. Poszanowanie żydowskiej odrębności przez Mickiewicza wypływało z fundamentalnego poszanowania mistyki żydowskiej, poszanowania, które sięgało przecież czasów filomackich i tuhanowickich. Zaś podstawą mistyki żydowskiej, z jaką poeta mógł się zetknąć, było pojęcie chasidut, któremu odpowiada łacińskie pietas, co opisowo da się przełożyć jako „kochać świat w Bogu” ${ }^{26}$. Konsekwencją tej postawy było przekonanie o samozbawczej roli człowieka w świecie. Człowiek jest więc „drabiną postawioną na ziemi, a sięgającą swym szczytem nieba”, zaś „Wszystkie jego gesty, interesy i mowy pozostawiają ślady w górnym świecie" ${ }^{27}$. Chasydyzm - za Kabała - wygnanie z Raju interpretował jako powierzenie ludziom zbawczej misji w świecie. Misję taką winna - w koncepcji Mickiewicza - mieć emigracja. Do pełnienia tej misji zobligowane wręcz były wybrane, wiedzące więcej jednostki. Badacz myśli Martina Bubera, Jan Garewicz pisze, iż obowiązkiem ludzi jest wręcz włączanie „zaświatów w świat doczesny”, by mogły „w nim działać i go kształtować, tak jak dusza kształtuje ciało”28.

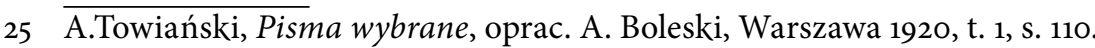

26 M. Buber, Słowo wstępne w: tegoż, Rabbiego Izraela ben Eliezera zwanego Baal Szem Towem to jest Mistrzem Dobrego Imienia pouczenie o Bogu zestawione z okruchów, przeł. J. Doktór, Warszawa 1993, s. 5.

27 Tamże, s. 12.

28 J. Garewicz, Wstęp, w: M. Buber, Gog i Magog. Kronika chasydzka, przeł. i wstępem opatrzył J. Garewicz, Warszawa 1999, s. XXI. 
Świat boski w mistyce żydowskiej nie tylko styka się ze światem ludzkim, ale jest z nim połączony wielokrotnymi relacjami o charakterze zwrotnym. Mariusz Prokopowicz pisze nawet, że „ezoteryczna wizja świata mistyki kosmologicznej pokazuje komplementarność sfer niebiańskich i ziemskich, które tworzą układ «naczyń połączonych»"29. W jakimś sensie ów system został otwarty na świat przez zburzenie Drugiej Świątyni i rozpoczęcie wielkiej diaspory. Wcześniej świat był domeną ładu, zburzenie Świątyni spowodowało objawianie się Boga już nie tylko na wzgórzu Moria, ale w całym świecie. Naczynia połączone, które w świecie starożytnym łączyły Bożą Obecność (En Sof) z ziemią narodu wybranego, teraz oplotły cały świat, dając możliwość uczestniczenia w zbawczej misji wszystkim, nawet najmniej zasłużonym i uduchowionym ludziom.

Jesteśmy tu o krok od pojęcia teurgii, którą znawca kabały, Charles Mopsik, definiuje jako „sztukę sięgania do tego, co boskie, lub doprowadzanie do określonych skutków w sferze boskiej, ale wyłącznie w celach odkupicielskich, nie zaś egoistycznie osobistych, jak to jest na ogół w przypadku ma-

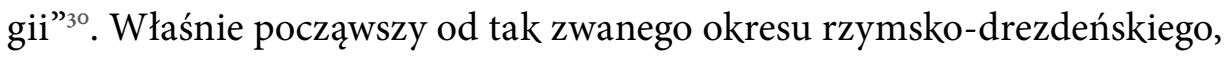
a może nawet wcześniej, począwszy od poddania się petersburskiej aurze martynizmu i sugestywnej osobowości Józefa Oleszkiewicza, poszczególne wydarzenia historyczne Mickiewicz interpretował jako teofanię. I realizm Mickiewicza nie był funkcją jego pamięci ani malarskiego oka, lecz wynikał z szacunku do pisma, zaś pismem, w którym ani joty nie wolno zmienić, była historia. Skoro bowiem w czymś tak poślednim, jak krzak gorejący objawił się Mojżeszowi Boży Majestat ${ }^{31}$, to dlaczego nie miał objawić się w procesie filomatów i filaretów?, na polach bitewnych powstania listopadowego?, we wszystkich wysiłkach emigracji?, we włoskiej irredencie i wydarzeniach Wiosny Ludów?, wreszcie, w działaniach militarnych wojny krymskiej?

W okresie towianistycznym Mickiewicz w swej lekturze Biblii wracał wciąż do Księgi Wyjścia, widząc w niej prefigurację współczesnych wydarzeń: Towiański to Mojżesz, Aaron - to Mickiewicz („brat jego wymowny”), wreszcie ostatni element analogii - lud izraelski - to emigracja - „lud niekarny, szemrzący, bałwochwalczy”32. Po 1846 roku, gdy założył już własne Koło, stał się jednocześnie Mojżeszem i Aaronem. To jemu właśnie objawiała

29 M. Prokopowicz, Wprowadzenie, w: Ksiega Jecirah. Klucz kabały, tłum. M. Prokopowicz, Warszawa 1994, s. XIV.

30 Ch. Mopsik, Kabała, przeł. A. Szymanowski, Warszawa 2001, s. 7.

31 Por. Boska pieczęć. Mądrości Talmudu, wyb. i przekład z hebrajskiego A. Klugman, Wrocław 2000, traktat Midrasz Raba 2, s. 117.

32 Por. M. Czapska, Szkice mickiewiczowskie, Warszawa 1999, s. 248. 
się Boża Obecność w Historii, on tylko mógł, odczytawszy znaki, pokierować działaniami ludzi tak, by sprowokować, nawet wymusić na Bogu wytęsknioną przemianę świata. Dlatego, jako mistyk właśnie, musiał negować współczesny mu ład polityczny. Aleksander Chodźko zapisał słowa Mickiewicza, które ukazują właśnie politykę nie jako dążenie do władzy doczesnej, ale wiecznej:

Ludzie stojący dziś u steru cywilizacji i rządów - to fałsz wcielony. Realizują oni słowo Boże o tyle tylko, o ile pomaga do wygodniejszego bytu na ziemi; oni chcą, aby Bóg pomagał duchowi służyć materii, oni przez niebo zdobywają ziemię. Jest to bój o władzę Królestwa Bożego z królestwem ziemskim. ${ }^{33}$

Co jednak można zrobić, gdy nie dysponuje się potęgą militarną, gospodarczą, polityczną, finansową, a pragnie wyrzeźbić od nowa postać świata? Romantyczny przywódca, jakim był Mickiewicz, rozumiał, że jedyną drogą wiodącą do przemiany jest pochodzące z mistyki żydowskiej działanie tikkun - odnalezienie sposobu wpłynięcia przez człowieka na sterowane przez Boga losy świata. Pierwszym zapisem tikkun były targi Abrahama o losy Sodomy i Gomory ( $\mathrm{Rdz} 18,22-33)$. To wola człowieka modelowała wolę Boga. Wystarczyć miało dziesięciu sprawiedliwych, by ocalić pogrążone w grzechu miasta. Mickiewicz poszukiwał właśnie takiej drogi dialogu z Bogiem. W jakimś stopniu Wielką Improwizację można interpretować jako - jednostronną wprawdzie - próbę wprowadzenia tikkun. Później poeta wciąż poszukiwał tego sposobu, który słabego i skończonego człowieka uczyniłby potężnym, nieskończonym.

Znamienną próbę podjęcia tikkun, stworzenia przez Mickiewicza minjanu wobec którego Bóg nie mógłby zostać obojętny, odnajdujemy w relacji Michaiła Bakunina. Otóż

[...] opowiadając carowi o swoich spotkaniach z Mickiewiczem, Bakunin sprowadzał je do próby nawrócenia go na towianizm: „Mickiewicz starał się mnie nawrócić, bo jego zdaniem dość było, żeby jeden Polak, jeden Rosjanin, jeden Czech, jeden Francuz i jeden Żyd zgodzili się żyć i działać pospołu w duchu Towiańskiego, żeby dokonać przewrotu w świecie i przynieść mu wybawienie; Polaków miał pod dostatkiem, byli i Czesi, byli też Żydzi i Francuzi, brak było tylko Rosjanina; chciał więc mnie zwerbować, ale mu się nie udało" ${ }^{34}$

Prawdomówność Bakunina potwierdza sam Mickiewicz, gdy mówi o sprawie, która „[... jest dla Izraela i w Izraelu, i przez Izraela. Dla niezgłębionych

33 Adama Mickiewicza wspomnienia i myśli, s. 297.

34 Cyt. za: A.A. Kamiński, Trójca wieszczów a Michał Bakunin, w: Mickiewicz, Słowacki, Krasiński, red. E. Owczarz, J. Smulski, Łowicz 2001, s. 51. 
pańskich wyroków przeprowadza je Pan od wieków w trzy pokolenia, to jest wstawia je w Izraela Żyda, wciela w Izraela Francuza i w Izraela Słowianina" ${ }^{35}$.

Właśnie na tym polega tajemnica legionu żydowskiego. Ostatniej ziemskiej inicjatywy Mickiewicza - mistyka. Mistyka jest bowiem pewną postawą, charakteryzującą zarówno wiarę, jak i poznanie, os nuta zaś jest wokół wielu paradoksów: świat rzeczywisty w ekstazie mistycznej staje się światem na opak, bo rzeczywistym (a więc normalnym) dla mistyka staje się świat duchowy; wznoszenie się mistyka ku Bogu staje się zapadaniem w głąb siebie; osiągnięcie najgłębszej wiedzy polega na wyzbyciu się całej mądrości ziemskiej etc. I tylko droga mistyczna może prowadzić do zrozumienia i przyjęci a historyczności objawienia się Boga człowiekowi. Ksiądz profesor Jan Andrzej Kłoczowski pisze, że historyczność teofanii

[...] była i jest źródłem zgorszenia, źródłem skandalu intelektualnego i jedną z istotnych przyczyn sprzeciwu wobec chrześcijaństwa, czy wobec religii biblijnej w ogóle. Sprawa da się wyrazić następująco: czy jest możliwe, aby Absolut dał się poznać człowiekowi poprzez mediację przypadkowych wydarzeń historycznych? ${ }^{36}$

Ten „skandal intelektualny” najpełniej jednak charakteryzuje postawę Mickiewicza, który właśnie w ułomnych w swej incydentalności faktach dostrzegał wcielanie się, czyli objawianie Boga w historii. Tym samym Mickiewicz w najgłębszej strukturze swojego myślenia dokładnie odwzorowywał strukturę myślenia biblijnego. Istotą tego myślenia jest akceptacja paradoksalności. Wobec kosmicznego, boskiego ładu rzeczywistość ludzka będzie w każdym swym wymiarze paradoksalna. Dlatego - wróćmy do legionu żydowskiego - ta inicjatywa była w przekonaniu Mickiewicza niezrozumiała dla współczesnych. Nawet jeśli deklarowali powierzchownie jej poparcie. I ma rację Janusz Ruszkowski, gdy pisze, że w wydarzeniach wojny krymskiej upatrywał Mickiewicz syntezę judaistycznych i krucjatowych projektów przemiany świata, początku realizacji profecji apokaliptycznych, początku budowy „Nowej Jeruzalem" ${ }^{37}$, ale narzędziem owej przemiany nie miała być sama wojna, lecz właśnie formacja żydowska, pojawienie się na scenie wojennego teatru nowych Machabeuszy. To miał być ów nieodkryty punkt archimedesowy, którego użycie umożliwiało pojedynczemu nawet człowiekowi wpłynięcie na wolę Boga, a tym samym zmianę biegu historii, odnowienie oblicza Ziemi.

Współudział Adama Mickiewicza w Sprawie Andrzeja Towiańskiego, Paryż 1877, t. 1, s. 219.

36 J.A. Kłoczowski, Drogi człowieka mistycznego, Kraków 2001, s. 139.

37 J. Ruszkowski, Adam Mickiewicz i ostatnia krucjata. Studium romantycznego millenaryzmu, Wrocław 1996, s. 247 i n. 
W całej palecie paradoksów, jakimi posługiwać się musiał Mickiewicz mistyk, nie brakuje też swoistego utożsamienia judaizmu i chrześcijaństwa. Jak zapisał przywoływany już Chodźko, Mickiewicz twierdził, że

Rzymianie tylko jeden naród nienawidzili: Żydów, i z takim okrucieństwem męczyli chrześcijan, bo czuli duchem, że idea izraelska podbija ideę rzymską i że kilku ludzi wyszłych z Jeruzalem, które im hołdowało, zatknie wśród posągów rzymskich krzyż, a na świątyniach bóstw rzymskich wzniesie pierwszą stołeczną bazylikę chrześcijańską. ${ }^{38}$

Tak samo idea zmieniająca współczesny kształt świata musi być odrzucana, opluta, poniżona. I chociaż legion żydowski był ideą paradoksalną̧a , chociaż nie został on nigdy powołany do istnienia, to jednak antycypował rehabilitację wojskową Żydów, przywrócenie na mapie świata państwa żydowskiego, wreszcie, wiążąc historię z teofanią, dążył do "przebóstwienia” świata. Miał być osiągnięciem i odgadnięciem boskiej doskonałości „na skróty”, nie ewolucyjnie, lecz w jednym rozbłysku zbrojnego czynu. Na mapie tego odnowionego świata miała też znaleźć się Polska, nie „kształtu dawnego”, lecz nowa, oddana Bogu i boskiemu prawu.

Mickiewicz stawał się tu człowiekiem religijnym na modłę pierwszych chrześcijan. Właśnie tych, którzy nie zerwali jeszcze całkiem swoich więzi z judaizmem, nie odcięli się od żydowskich korzeni. W pierwszych wiekach chrześcijaństwa teologia nie była jeszcze oddzielona od historii pojmowanej jako teofania, a zatem romantyczne przedstawienie historii jako sfery objawienia się Boga było w jakimś sensie powrotem do pierwotnej, unitarnej teologii ${ }^{40}$.

Adama Mickiewicza wspomnienia i myśli, s. 270-271.

39 Rafał Marceli Blüth pisze przekonująco, że idea legionu była: „dziwną w swym mistycznym paradoksalizmie, alogiczną koncepcją chrześcijańskiego syjonizmu” (R.M. Blüth, Konstantynopolska katastrofa, w: Pisma literackie, oprac. P. Nowaczyński, Kraków 1987, s. 101). O presyjonizmie Mickiewicza pisze też Janion w artykule opublikowanym w „Midraszu” (dz. cyt., s. 33-35). O czynie Mickiewicza zob. także: J. Maurer, „Jak mnie nie stanie, nikt tego nie zrozumie". O legionie żydowskim Adama Mickiewicza, w: Polonistyka po amerykańsku. Badania nad literatura polska w Ameryce Pótnocnej (199o-2005), red. H. Filipowicz, A. Karcz, T. Trojanowska, Warszawa 2005, s. 116. Ciekawe, że zupełnie współcześnie Legionem żydowskim Mickiewicza zainteresowali się badacze/ artyści, podejmując inicjatywę, którą nazwali Migrującym Uniwersytetem Mickiewicza w Stambule. W ramach tej inicjatywy projektantka mody, Anna Kuczyńska, w roku 2014 zaprojektowała współczesną wersję munduru legionisty żydowskiego (na plecach naszytą ma - nie wiedzieć czemu - rękę Fatimy; zarazem cała inicjatywa ma na celu ożywienie stambulskiego Muzeum Adama Mickiewicza (por. Migrujący Uniwersytet Mickiewicza w Stambule [online], Culture.pl [dostęp: 2015-11-26]: <http://culture.pl/pl/ wydarzenie/migrujacy-uniwersytet-mickiewicza-w-stambule $>$ ).

40 Por. J. Ratzinger, Wprowadzenie w chrześcijaństwo, tłum. Z. Włodkowa, Kraków 2006, s. 341 i n. 


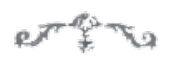

A B S T R A C T

\section{Jewish Legion - a Mystical Testament of Adam Mickiewicz}

The research purpose of the article is to formulate a proper assessment of Mickiewicz's last initiative - the formation of the so-called Jewish Legion during the Crimean War. The applied methodology, the hermeneutics of literary and biographical meanings requires an approach from the perspective of the entire oeuvre of the poet. The Jewish Legion was to be a fully material work of art, empirically distinct, and at the same time it was supposed to point to a spiritual backstage of earthly realities. The reality was only supposed to - as in the earlier works of Mickiewicz - point to a transcendent realm. The Jewish Legion was also an attempt to start the intervention of Providence in human history; it was supposed to be a kind of modern tikkun, force God's actions in human history. In the adopted research perspective The Jewish Legion reveals its multiplicated face. It is a testament of Mickiewicz's historicism and faith, which drew inspiration from both Christianity and Judaic traditions.

KE Y W OR D S

Adam Mickiewicz, Jewish Legion, Crimean War, tikkun 